補綴誌, J Jpn Prosthodont Soc, 36:746〜760, 1992.

原著論文

\title{
機能運動時の咬合接触およびクリアランス
}

大久保由紀子坂東 永一

\section{Occlusal Contact and Clearance in Functional Mandibular Movement}

\author{
Yukiko Okubo and Eiichi Bando
}

\begin{abstract}
We previously reported the three-dimensional analyzing system of occlusal tooth contacts. Using this system, we studied the functional tooth contacts and clearance of five subjects particularly during masticatory movements.

1. Tooth contacts and interocclusal clearance less than $1 \mathrm{~mm}$ can be analyzed during functional mandibular movements by using the six-degree-freedom jaw movement data and the three -dimensional morphology measurement of tooth surfaces.

2. Dominant tooth contacts were observed on the non-chewing side than on the chewing side during masticatory movements. The tooth contact sites on the non-chewing side corresponded to the region of contacts or tiny clearance which occurs during mediotrusive movement.

3. Tooth contacts and clearance at the beginning and the end of chewing cycle (jaw opening and jaw closing) were compared with those during lateraI excursive movement. Tooth contacts and clearance during masticatory movement toward opening more corresponded to those during lateral excursive movement.

In summary, the non-chewing side tooth contacts may play an important role in the support and guidance of mandible throughout the functional masticatory movements. That means there is a need for more precise evaluation regarding non-working side occlusal tooth contacts in functional movements.
\end{abstract}

Key words : tooth contact, occlusal clearance, lateral excursive movement, masticatory movement

徳島大学崡学部歯科補緅学第 2 陆座 (主任：坂東永一教授) Department of Fixed Prosthodontics, School of Dentistry, The University of Tokushima (Chief : Prof. Eiichi Bando) 平成 4 年 2 月 7 日受付

\section{I. 緒 言}

機能的に望ましい咬合面形態および咬合関係の探求 は補緅学における最も重要な研究課題の1つである. 特に咀噃運動は頡口腔系の総合的な機能運動として重 要視され，歯の咬合面形態を考える場合においても咀 
曙運動路との調和という点に関心がもたれている.

咀㗄運動路に関しては，咬頭嵌合位付近における歯 の接触滑走の有無あるいは咬頭傾斜との関係などにつ いて様々な見解が述べられてきたが，藍”により切歯 点部における咀獣運動路は咬頭嵌合位付近で側方滑走 運動路と近似した関係にあることが明らかにされて以 来, 側方滑走運動と咬合面形態の関係について多くの 研究成果が報告されてきた2 6). しかし平面投影され た運動経路から 3 次元的な咬合面形態を推測するには 限界があり，また機能運動時のあらゆる䫇位における 上下頻歯列の位置関係を再現するのは容易なことでは ない.

著者らは䫑運動と咬合面形態の関係を明らかにする ための一助として, 咬合接触の 3 次元解析システムを 開発し報告した7). 本論文ではこのシステムを側方滑 走運動および前方滑走運動, さらには咀罚運動にも応 用し, 機能運動時の咬合接触およびクリアランスにつ いて定性的および定量的な解析を試みた.

\section{II. 研究方法}

\section{1. 被験者}

被験者は頻口腔系に異常を認めない年齢 26 歳から 43 歳までの咬頭嵌合位が明確な歯列を有する成人男 性 4 名，女性 1 名の計 5 名である。なお被験者 1 およ び被験者 2 は健全な天然歯列を有しており，他の 3 名 についてはなんらかの歯冠補綴物を有していた（表
$1)$.

\section{2. 実験方法}

歯列の 3 次元形態計測方法および額運動データとの 对応については，すでに報告した7のので簡単に述べ る.

1）歯列の 3 次元形態の計測

歯列模型の 3 次元形態の計測には, CNC 三次元測 定機（ミツトヨ社製，マイクロコード FN 503）を使 用し, 測定子には半径 $0.25 \mathrm{~mm}$ の球状測定子を使用 した. 計測は歯の輸郭に沿って $250 \mu \mathrm{m}$ 間隔で行っ た. 計測データはワークステーション (DEC 社製, VAX STATION 3520）に転送後, 球状測定子の半径 補正を行った。なお被験者 1 から被験者 4 については 顎運動測定用のメタルシーネを装着しない状態でシリ コーン・ラバー印象材（ジーシー社製, HYDROPHILIC EXAFLEX) を用いて印象採得を行った。また 上下穎歯列模型座標系の対応はグラフィックターミナ ル上での視覚的な重㭘せにより行い，下頡歯列模型 に取り付けた鋼球を指標とする重ね合せは行っていな い. 被験者 5 については先の報告》どおり,メタル シーネを装着した状態でチオコール・ラバーベース印 象材 (ジーシー社製, SURFLEX F RECULAR TYPE) を用いて印象採得を行い, 上下顎歯列模型の 重ね合せは鋼球を指標とする方法により行った。

2）頻運動の測定

顎運動の測定には，ディジタル方式澦運動測定器

表 1 被験者

\begin{tabular}{|c|c|c|c|c|}
\hline 被験者 & 性別 & 年齢 & 口腔内状態 & $\begin{array}{l}\text { 習慣性 } \\
\text { 咀䚇側 }\end{array}$ \\
\hline 1 & 男 & 43 & 健全天然齿列 & 左 \\
\hline 2 & 男 & 31 & 健全天然歯列 & 左 \\
\hline 3 & 男 & 38 & 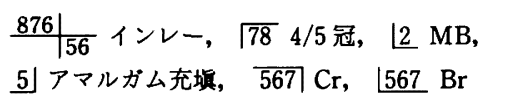 & 右 \\
\hline 4 & 男 & 26 & 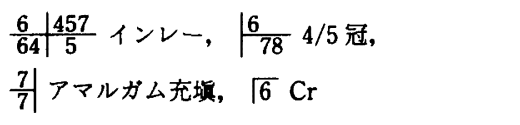 & 右 \\
\hline 5 & 女 & 27 & 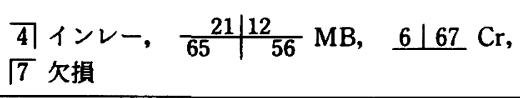 & 右 \\
\hline \multicolumn{5}{|c|}{$\begin{array}{l}\mathrm{MB}: \text { 金属焼付陶材冠 } \\
\mathrm{Cr} \text { : 全部鋳造冠 }\end{array}$} \\
\hline
\end{tabular}


$(\mathrm{MM}-\mathrm{JI})^{8)}$ を使用した。解析に用いた顎運動は，左 右側方滑走運動，前方滑走運動および咀嚼運動であ る. 左右側方滑走運動については, 咬頭嵌合位から接 触滑走を行いながら偏心位へ向かい, さらに偏心位か ら咬頭嵌合位へ戻る往復運動を記録した。この場合の 咬頭嵌合位からの滑走運動を側方滑走開口運動, 咬頭 嵌合位へ戻る滑走運動を側方滑走閉口運動と呼ぶこと にする．なお一般的に側方運動に限らず，滑走運動の 運動方向を明示する場合には，咬頭嵌合位からの運動 には開口を, 咬頭嵌合位へ向かう運動には閉口をつけ ることにする，咀嚼運動については被験食品にガムお よびピーナッツを用い，ガムは十分こなれた状態で， ピーナッツは咬み初めから嚥下までの左右を指定した 片側咀嚼運動を記録した。

\section{3. 解析方法}

1）解析の対象とした顎位

左右側方滑走運動および前方滑走運動については, 下顎切歯点の移動距離が咬頭嵌合位から約 $3 \mathrm{~mm}$ まで

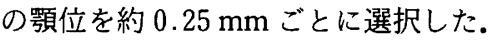

咀礵運動については, 閉口路上で下顎切歯点の移動 距離が咬頭嵌合位から約 $2 \mathrm{~mm}$ となる顎位から咬頭嵌 合位付近を通過して開口路上で下箩切歯点の移動距離 が咬頭嵌合位から約 $2 \mathrm{~mm}$ となる顎位へ至る連続した 運動経路上の約 $0.25 \mathrm{~mm}$ ごとの顎位を選択した。

2）咬合接触およびクリアランスの評価

前述の顎位における上下顎歯列のすべての計測点に ついて対顎との咬合小面間距離が $1 \mathrm{~mm}$ 以下となる点 を求めた。またその距離を $50 \mu \mathrm{m}$ 以下， $100 \mu \mathrm{m}$ 以 下, $150 \mu \mathrm{m}$ 以下, $200 \mu \mathrm{m}$ 以下, $300 \mu \mathrm{m}$ 以下，500 $\mu \mathrm{m}$ 以下, $1 \mathrm{~mm}$ 以下の 7 段階に分類して検討し, グ ラフィックターミナル (EVANS \& SUTHERLAND 社製，PS 390）上には色分けして表示した。なお本 論文中では先の報告 ${ }^{7}$ と同様に $200 \mu \mathrm{m}$ 以下の咬合小 面間距離を咬合接触, $200 \mu \mathrm{m}$ 以上の咬合小面間距離 をクリアランスとして記述する。

\section{III. 結 果}

\section{1. 咬頭嵌合位における咬合状態}

図 1 (被験者 1), 図 2（被験者 2）に咬頭嵌合位 における咬合状態の例を示す。

被験者 1 は比較的咬耗の進んだ状態で，明確な境界 を示す咬合小面を有しており，大臼歯部における咬合
接触はほぼすべての咬合小面において，それぞれの咬 合小面内全体に広い範囲で認められた。しかし犬歯お よび小臼歯においては広い咬合小面を有しているにも かかわらず,咬合接触は咬合小面内の一部に限られ,特 に右側上下犬歯には $300 \mu \mathrm{m}$ 以下ではあるがクリアラ ンスが存在し, 咬合接触はほとんど認められなかった. 被験者 2 においては，上顎左右第 1 大臼歯の舌側咬 頭内斜面一下䫵左右第 1 大臼歯煩側咬頭内斜面間に広 く咬合接触が認められるが，上顎左右第 1 大臼歯煩側 咬頭内斜面一下顎左右第 1 大臼歯煩側咬頭外斜面間に は咬合接触が認められず, 他の 4 名の被験者とは異 なった傾向を示した.

\section{2. 滑走運動時の咬合状態}

1）左右側方滑走運動

（1）左右側方滑走開口運動時の咬合状態

図 3 は, 被験者 2 について下顎切歯点の移動距離が 咬頭嵌合位から約 $2 \mathrm{~mm}$ の䂓位における左右側方滑走 開口運動時の咬合状態を示したものである.

作業側では，左右側方滑走開口運動ともに中切歯か ら最後臼歯にかけて咬合接触が認められた. 主な咬合 接触部位は上額では, 犬歯の遠心斜面, 第 1 , 第 2 小 臼歯の頖側咬頭遠心斜面であり，第 1 ，第 2 大臼歯の 近心舌側咬頭外斜面に点状の接触が認められた。 下澦 では, 第 1 , 第 2 小臼歯の煩側咬頭近心斜面, 第 1 大 臼歯近心煩側咬頭近心斜面に咬合接触が認められ，さ らに第 1 , 第 2 大臼歯の遠心舌側咬頭内斜面に点状の 接触が認められた。

平衡側では, 右側方滑走開口運動時に上顎左側第 1 , 第 2 大臼歯舌側咬頭内斜面扝よび下顎左側第 2 大 臼歯棘側咬頭内斜面に咬合接触が認められた。 また左 側方滑走開口運動時には上效右側第 1 , 第 2 大臼歯舌 側咬頭内斜面および下䫟第 2, 第 3 大臼歯煩側咬頭内 斜面に $300 \mu \mathrm{m}$ 以下のクリアランスを示す部位が認め られ，咬合接触とはいえないまでも上下顎咬合小面が かなり近接した状態であることが示された。

すべての被験者について左右側方滑走開口運動時の 咬合状態を総括的に述べると, 作業側の犬歯, 小臼歯 部においては, 咬頭嵌合位では咬合接触していない咬 合小面にも咬合接触が認められ，接触部位は滑走運動 の䋶位の進行とともに同一咬合小面内を上䫑では煩側 方向に, 下買では舌側方向に移動していた.

また側方滑走運動のガイドとなっていると考えられ る部位では, 同一咬合小面内でその接触面積が増大し 

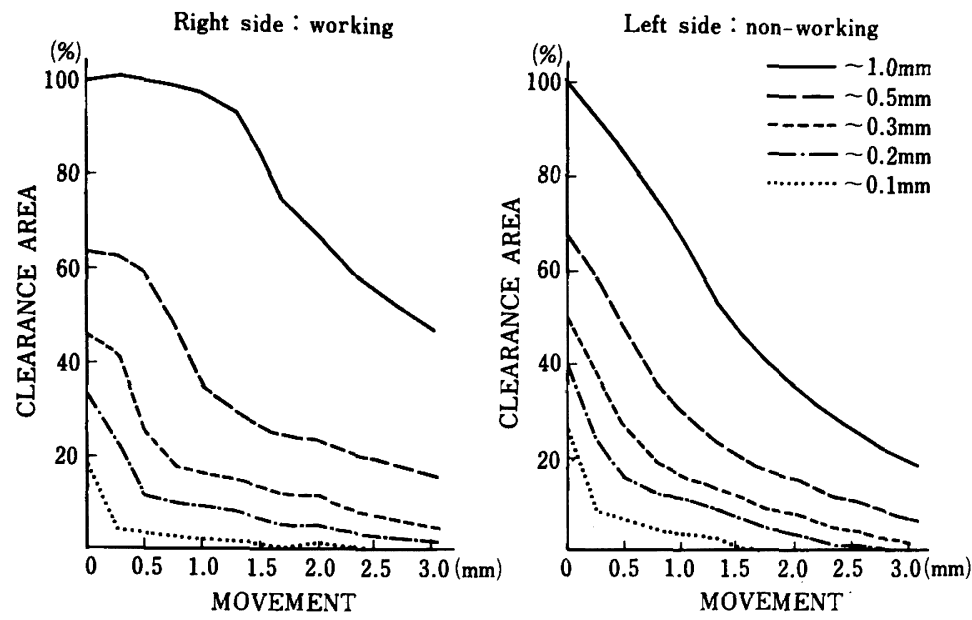

図 4-a 右側方滑走開口運動時の咬合状態の変化（被験者 2）
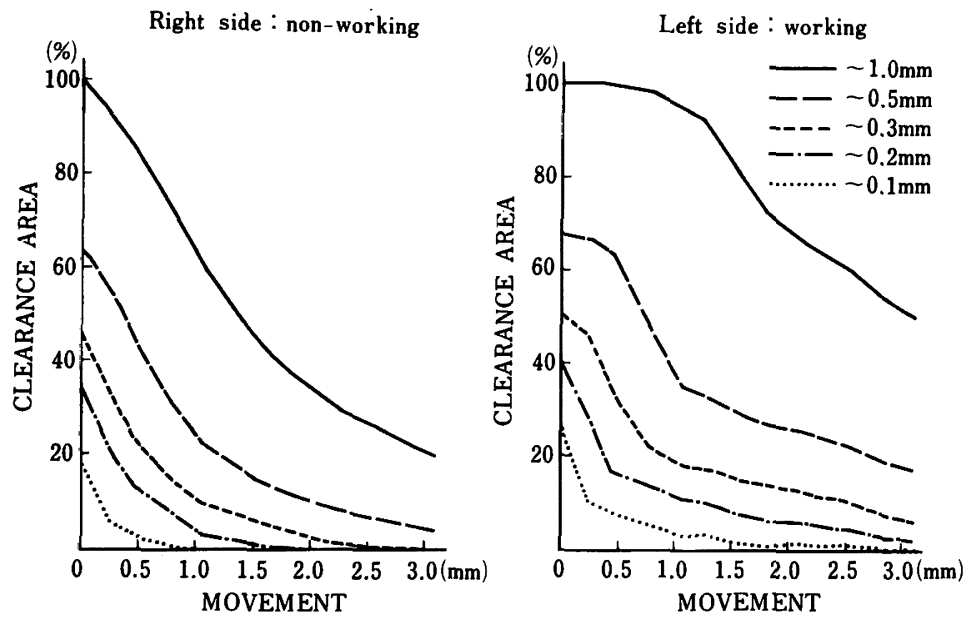

図 4-b 右側方滑走開口運動時の咬合状態の変化（被験者 2)

ている場合が多く認められた，臼歯部においては，咬 頭炭合位において咬合接触が認められる咬合小面内の 一部に接触が認められ，䫑位の進行とともに面状の咬 合接触が線状あるいは点状の接触へと変化する場合が 多かった．そのほかガイドとなっている咬合小面が， 影位の進行とともに変化している例も認められた。 た下頞切歯点の移動距離が咬頭嵌合位から約 $3 \mathrm{~mm}$ の 䫕位においても平衡側の上頻臼歯部舌側咬頭内斜面一 下影臼歯部煩側咬頭内斜面間のクリアランスは $1 \mathrm{~mm}$ 以下であり，なかでも上顥第 2 大臼歯舌側咬頭内斜面 一下颚第 2 大臼歯煩側咬頭内斜面間（第 2 大臼歯欠損 の場合は第 1 大臼菌とした）でクリアランスが 500 $\mu \mathrm{m}$ 以下となる例が 10 例中 8 例に認められ, この部 位に最も平衡側接触が生じやすいことが示された。
(2) 咬合接触およびクリアランスの変化

図 4 は被験者 2 の左右側方滑走開口運動について, 咬頭嵌合位における $1 \mathrm{~mm}$ 以下の咬合小面間距離をも つ部位の面積を $100 \%$ としたときの下額切歯点の移動 量と，それに伴う各咬合小面間距離を示す部位の面積 の変化の様子を作業側, 平衡側に分けて示したもので ある。

いずれの咬合小面間距離においても下䅡の移動とと もにその面積は減少傾向を示し, 作業側の変化傾向が 緩やかであるのに対して，平衡側では急速に減少する 傾向が認められた。 また作業側，平衡側ともに下䂭切 歯点の移動距離が咬頭倣合位から約 $1 \mathrm{~mm}$ 程度までの わずかな範囲においては，咬合小面間距離が長いもの ほどグラフの傾きは緩やかであった，すなわち $1 \mathrm{~mm}$ 


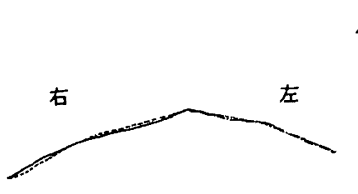

Analysis point : Incisal point

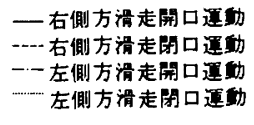

$1 \mathrm{~mm}$

(水平面)
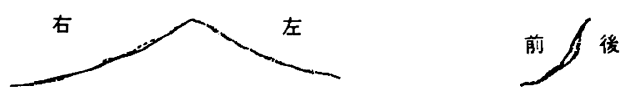

(前頍面)

(矢状面)

図 5-a 左右側方滑走開閉口運動路

(被釦者 1 ：切歯点部)

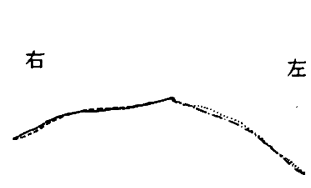

Analysis point : Right 1st molar

右側方滑走閏口的

--- 右㑡方滑走閉口婵動

- - 左側方滑走開口通的

……左側方滑走閉口要缜

$1 \mathrm{~mm}$

(水平面)

右左

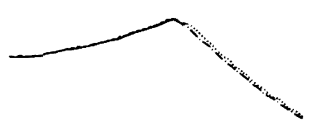

前

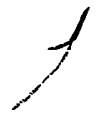

(前頭面)

(矢状面)

図 5-b 左右側方滑走開閉口運動路

（被験者 $1 ：$ 右側第 1 大臼菌部）

以下のクリアランスを示す部位の面積は, とりわけ作 業側では下顎切歯点の移動距離が咬頭嵌合位から約 1 $\mathrm{mm}$ までの範囲ではほとんど変化していないが, 100 $\mu \mathrm{m}$ 以下の咬合接触を示す部位の面積は, 下顎切歯点 の移動距離が咬頭嵌合位から約 $0.25 \mathrm{~mm}$ でも大きく 変化した。この傾向は他の被験者についても同様で あった。

（3）側方滑走運動の開口路と閉口路について

側方滑走開口運動路（開口路）と側方滑走閉口運動 路（閉口路）について，その運動経路および咬合状態 の相違を検討した。

図 5 に被験者 1 の切歯点および左右第 1 大臼歯部に おける左右側方滑走運動の開口路ならびに閉口路の 3 平面投影図を示す。運動経路でみると，切歯点では両

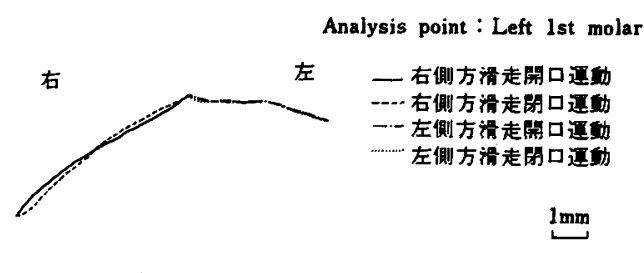

(水平面)

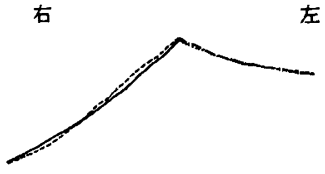

(前頭面)

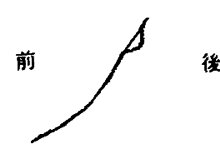

(矢状面)
図 5-c 左右側方滑走開閉口運動路

(被験者 1 : 左側第 1 大臼䠛部)

運動経路がほぼ一致している場合でも臼歯部では相違 が認められた.すなわち前頭面投影図でみると, 平衡 側臼歯部では閉口路は開口路よりも上方の経路をとる 傾向があり，作業側臼歯部では上下的には両運動経路 は切歯点よりも一致する傾向があった，水平面あるい は矢状面投影図でみて両運動経路に前後的な差が認め られる場合でもこの傾向は変わらなかった。

被験者 1 の左側方滑走運動の開口路と閉口路上にお いて, 下顎切歯点の移動距離が咬頭嵌合位から約 1.5 $\mathrm{mm}$ の顎位における咬合状態を図 6 に示す.作業側 （左側）の咬合状態にはほとんど相違はみられないが， 平衡側 (右側) では上下顎第 2 大臼歯にみられる咬合 接触部位の面積が開口路に比較して閉口路の方が大き く, $1 \mathrm{~mm}$ 以下のクリアランスを示す部位の面積も閉 口路の方が大きかった。

この顎位における下顎の回転量の差は, 開口路を基 準として閉口路をみると, 顆頭間軸の前頭面投影角で 右が上方, 左が下方となる方向に $0.13^{\circ}$, 水平面投影 角で右が後方, 左が前方となる方向に $0.13^{\circ}$ 顆頭間軸

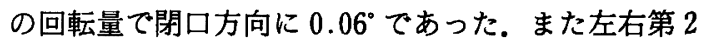
大臼歯部の中点の移動量の差は, 閉口路の方が後方へ $0.06 \mathrm{~mm}$, 右方向へ $0.08 \mathrm{~mm}$, 上方へ $0.04 \mathrm{~mm}$ あった。

2）前方滑走運動

（1）前方滑走開口運動時の咬合状態

図 7 は, 被験者 2 について下顥切歯点の移動距雕が 咬頭嵌合位から約 $1 \mathrm{~mm}$ の㖽位における前方滑走開口 運動時の咬合状態を示したものである.

咬合接触の認められる部位は上下額とも前歯部に限 

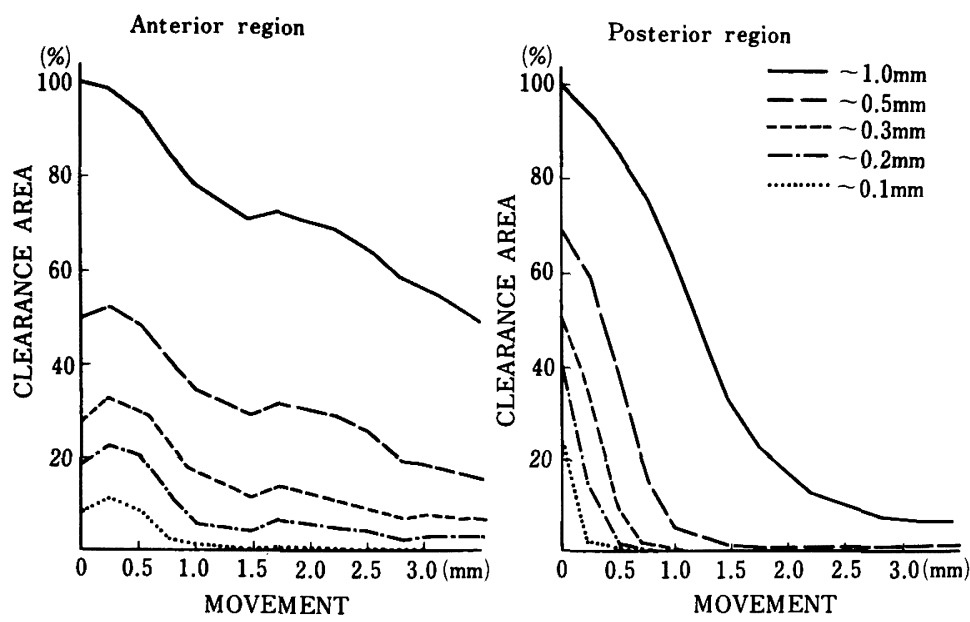

图 8 前方滑走開口運動時の咬合状態の変化（被験者 2)

局しており，臼歯部では咬頭嵌合位で咬合接触の認め られた部位に一致して $1 \mathrm{~mm}$ 以下のクリアランスが認 められた。

(2) 咬合接触およびクリアランスの変化

図 8 は, 同被験者について前方滑走開口運動時の咬 合状態の変化を前歯部，臼歯部に分けて側方滑走開口 運動時と同様に示したものである．前歯部において下

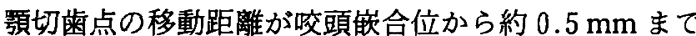
の範囲では, $500 \mu \mathrm{m}$ 以下のクリアランスを示す部位 の面積は咬頭嵌合位よりも増加していた。他の被験者 についても $1 \mathrm{~mm}$ 以下のクリアランスは咬頭嵌合位付 近では増加する場合があった。また臼歯部では咬合接 触を示す部位の面積は, 下頡切歯点の移動距離が咬頭 嵌合位から約 $1 \mathrm{~mm}$ までの範囲で急速に減少し, 約 3 $\mathrm{mm}$ の額位ではほほ四歯部全体に $1 \mathrm{~mm}$ 以上のクリア ランスが認められた。この傾向はすべての被験者につ いてほほ同様であった。

\section{3. 咀挐運勡中の咬合状態}

咀㘁運動については側方滑走運動との関連性を重視 し，すべてのストロークについて咬頭嵌合位付近の咀 喟運動路と側方滑走運動路を比較検討した。

1）任意点における咀嚼運動路について

図 9 は，被験者 4 の切歯点および左右第 1 大臼歯部 における左右側方滑走開口運動路と右側ガム咀嚼運動 路の 1 ストロークを重ねて表示し，さらに各経路を水 平面，前頭面および矢状面の 3 平面に投影した図であ る.ガム咀隠運動はガムが十分こなれた状態での運動 を記録しており，どの被験者においても比較的安定し
た咀嚼ストロークを示した。被験者 4 では記録された 17 ストロークすべてに咀嚼の第 5 相"'は認められず, 咀啷の開口路は最も咬み込んだ位置から再び右方向へ 開ロしていた。また逆ストロークも認められなかっ た.

切歯点における咀礵の閉口路は，前頭面投影図では 右側方滑走開口運動路よりも下方にあり，矢状面およ び水平面投影図では右側方滑走開口運動路よりも後方 にある.すなわち咀嚼の閉口時, 下顎の切歯点部は側 方滑走開口運動よりも後下方の経路をとって咬頭嵌合 位へと向かっていた，咀嚼の開口路はどの方向から観 察しても右側方滑走開口運動路にほぼ一致していた。 臼歯部においても前後的には切歯点と同様な傾向が認 められたが，右側第 1 大兒歯部（咀罚側）では閉口路 と開口路の上下的な差は切菌点よりもやや少なく, 開 口路は側方滑走開口運動路よりもわずかに上方の経路 を描いた。さらに左側第 1 大臼菌部（非咀兽側）では 閉口路は明らかに側方滑走開口運動路よりも上方の経 路をたどり，開口路は側方滑走開口運動路とほほ一致 していた。

咀緭運動路は個人差が大きく，また同一個人であっ ても食品によって異なった運動路を示すことが多いの で一概には断定できないが，咬頭嵌合位付近の咀嚼運 動路について次のような傾向が認められた。

咀嚼の閉口路は切歯点部でみると側方滑走開口運動 路に比較して後下方よりの経路をたどることが多く， 咀嚓側臼歯部においては非咀緭側臼歯部よりもやや後 方寄りにあり，側方滑走開口運動路より上方の経路を たどった．開口路は側方滑走開口運動に比較して前方 
への要素を持つ場合が多かった。

また粘着性食品であるガム咀噮では，閉口時よりも 開口時に側方滑走開口運動路と近似した運動路を描く 場合が多かった．粉砕性食品であるピーナッツ咀嚼の 場合，咀嚼の初期では下顎は咬頭嵌合位に戻らず，側 方滑走開口運動に近似した運動路は少ないが，咀嘪が 進行するに従ってガム咀嚼よりも咀罾の第 5 相が出現 する割合が多くなり，側方滑走開口運動に近似した部 分が長くなる場合が多かった。

2）咀罟運動中の咬合接触およびクリアランス

すべての咀嚼ストロークについて咬頭嵌合位付近の 咬合状態を観察することは困難であるので，平均的と 思われるストロークあるいは咀嚼の第 5 相の出現の有 無などに注目して，各運動ごとに 3 ストローク選択し て咀嚼運動中の咬合状態を検討した。

（1）ガム咀嚼運動

図 10 に被験者 4 の右側ガム咀嚼運動中の咬合状態 を示す. 図 10-a は咀嚼の閉口路上において下顎切歯 点の移動距離が咬頭嵌合位から約 $1.5 \mathrm{~mm}$ の顎位, 図 10-b は最も咬み込んだ澦位, 図 10-c は咀酃の開口路 上において下顎切歯点の移動距離が咬頭嵌合位から約 $1.4 \mathrm{~mm}$ の蕷位における咬合状態である.

咀㘁の閉口時, 咀罾側の上下顎犬歯，および上下顎 第 2 大臼歯にわずかな咬合接触が認められるが, 非咀 㘁側の上顎大臼歯舌側咬頭内斜面および下顎頓側咬頭 内斜面には咀嚼側よりも広い咬合接触が認められた。 非咀罚側に認められた咬合接触の部位は，右側方滑走 開口運動時には咬合接触がほとんど認められず，右側 方滑走閉口運動時にはわずかに咬合接触が認められた 部位と一致していた。また非咀嚼側に認められる 1 $\mathrm{mm}$ 以下のクリアランスを示す部位全体の面積は，側 方滑走閉口運動時よりも咀噮運動中の方が小さいにも かかわらず咬合接触部位の面積は大きかった。

最も咬み込んだ顎位では，咬頭嵌合位における咬合 状態にほほ一致していたが，咬頭嵌合位よりもわずか に後方で咬合しているょうであった。

咀糫の開口時は, 咀啷運動路からも推察できるよう に右側方滑走開口運動時のほほ同じ靧位における咬合 状態とおおむね一致していたが，上下䫓切歯の咬合接 触面積は咀酃の開口時の方が大きく, 咀喵運動中の方 がやや前方への要素をもつことがうかがえた。

図 11 は, 同じ咀礵運動の閉口路から咬頭嵌合付近 を通過して開口路に至るまでの各咬合小面間距離を示 す部位の面積の変化を咀哷側，非咀噮側に分けて滑走
運動と同様に示したものである. $100 \mu \mathrm{m}$ 以下の咬合 接触を示す部位は非咀㘁側で先に認められ，その面積 は最も咬み込んだ䫈位まで緩やかに増加しているが， 咀嚼側では閉口路上において下顎切歯点の移動距離が 咬頭嵌合位から約 $0.5 \mathrm{~mm}$ の顥位から急激に増加し た。逆に $1 \mathrm{~mm}$ 以下のクリアランスを示す部位の面積 は咀緭側の方が緩やかな増加傾向を示した．開口路上 では咀嚼側, 非咀嚼側ともに右側方滑走開口運動時の 咬合状態の変化と同様な傾向を示した。

（2）ピーナッツ咀嚼運動

被験者 4 の右側ピーナッツ咀嚼運動では咀緭初期の 3 ストロークには第 5 相は認められなかったが，4 4 ス トローク目から認められるようになった。 またガム咀 嚼運動路に比較して咀嚼の閉口時にその運動経路が側 方滑走開口運動路と近似している場合が多く, 咀罾の 開口時は側方滑走開口運動路よりも前方へ向かう経路 が多く認められた。

図 12 に被験者 4 の右側ピーナッツ咀嚼運動中の咬 合状態を示す。図 12-a は咬み初めから聴下までの全 ストローク中 5 ストローク目の閉口路上において下顥 切歯点の移動距離が咬頭嵌合位から約 $1.4 \mathrm{~mm}$ の頧 位, 図 12-b は最も咬み込んだ額位, 図 12-c は 6 ス トローク目の開口路上において下顎切歯点の移動距離 が咬頭嵌合位から約 $1.4 \mathrm{~mm}$ の䫑位における咬合状態 である。

咀噂の閉口時は，ガム咀嚼運動と同様な咬合状態を 示し, 咀顓側のみならず非咀嚼側臼歯部にも咬合接触 が認められた。

図 12-b は, 閉口路から開口路へと運動方向が急激 に変化した顎位を最も咬み込んだ顎位として表示し た.この顎位は咬頭嵌合位からの下影切歯点の移動距 離が最小となる顎位とは一致しない，最も咬み込んだ 顎位では明らかに咀嚼側よりも非咀嚼側に咬合接触部 位が多く認められ，前歯部では咬頭嵌合位におけるよ りも広い面積で咬合接触が認められた。

咀嚼の開口時は前方方向への要素が強く, 臼歯部て は咬合接触は急激に減少し, 図 12-c の䪽位では臼歯 部に認められる咬合接触はわずかであり, 前菌部に咬 合接触が多く認められた。この咬合状態は前方滑走開 口運動時の下頧切歯点の移動距離が咬頭岸合位から約 $1.5 \mathrm{~mm}$ における咬合状態とほほ一致しているが, 詳 細に観察すると前方滑走開口運動時と比較して左側上 下䫟犬歯, 小臼歯部に $1 \mathrm{~mm}$ 以下のクリアランスを示 す部位がわずかに多く，左方向への偏位をうかがわせ 


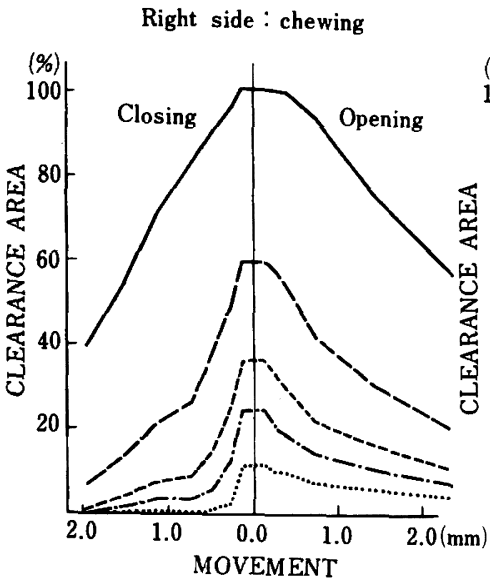

Left side : non-chewing

図 11 右側ガム咀喘運動中の咬合状態の変化（被験者 4)
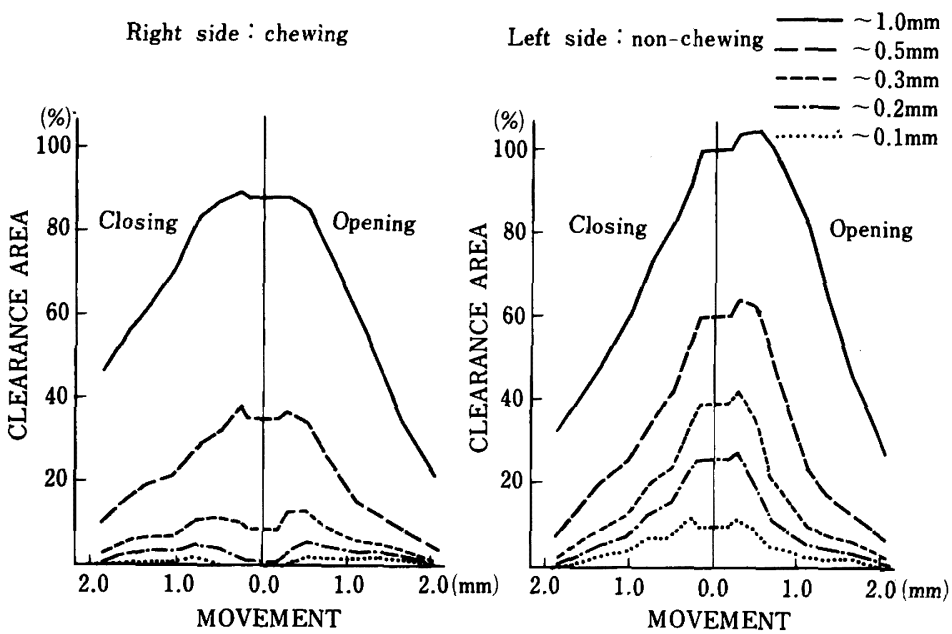

図 13 右側ピーナッツ呾㘁運動中の咬合状態の変化 (被験者 4)

た.

図 13 は, 同じ咀灀運動の咬合小面間距離の変化を 図 11 と同様に示したものである。咀嘎側, 非咀緭側 ともに咬合接触および $1 \mathrm{~mm}$ 以下のクリアランスを示 す部位の面積が最も大きい顎位は，咬頭嵌合位からの 下頡切歯点の移動距離が最小となる敛位ではなく，閉 口路から開口路へと運動方向が急激に変化した顎位と 一致していた。またどの咬合小面間距離においても非 咀嚼側の方がその面積は大きく，グラフからも非咀啳 側の方が咀䲇側よりも強く咬合していることが確認さ れた。

またピーナッツ咀㘁運動のように咀嚼の進行ととも に食品の形状が変化していくような場合には，ガム咀 夁に比較してその咬合状態も大きく変化していると考
えられる.そこでピーナッッ咀畄の咀嚼初期, 中期, および終末期の最も咬み込んだ颚位に注目して各頧位 における咬合状態を観察した。そ結果, 咀覆の初期 には咬合接触は非咀嚼側に多く認められたが，咀緭が 進行するに従って咀噮側にも咬合接触が認められるよ うになり，左右の上下影歯列がバランスよく接触し咬 頭嵌合位における咬合状態とほ涩一致した像を示すよ うになった後, 嚥下へと至った。

\section{IV. 考察}

\section{1. 解析方法について}

先に報告した歯列の 3 次元形態データと 6 自由度顎 運動デー夕を用いた咬合接触の 3 次元解析システムで 
は, $200 \mu \mathrm{m}$ 以下の咬合小面間距離をもつ部位を咬合 接触していると評価して解析の対象とした7). しかし 顎運動と咬合面形態の関係を明らかにするためには, 機能運動中の咬合接触のみならず歯の離開の程度をも 考慮する必要がある ${ }^{8,10)}$ という考えから解析システム を一部改良し, 咬合小面間距離が $1 \mathrm{~mm}$ 以下となる 部位までを解析対象とした。これにより咬合接触の有 無という観点からだけではなく，上下䋶咬合小面の近 接の可能性という点からも咬合面形態の意義を考察す ることが可能となった。 また咬合接触の閾值として採 用した $200 \mu \mathrm{m}$ が口腔内での咬合接触をどの程度確実 にとらえているかという点については，定量的には不 明な部分が残されているが，もう少し小さい別の值を 闇值と設定しても結果の傾向は変わらないことから, 機能時の咬合接触を考える最初のモデルとしては十分 な情報をもっていると考えることができる.

\section{2. 結果について}

1）滑走運動時の咬合状態について

滑走運動時には過大な咬合力はかからないと考えら れるので, 咬合力によって生じる歯の動摇11,12)や顎骨 の歪み ${ }^{13)}$ の影響は少なく, 本システムによってかなり 正確に口腔内のみならず顎口腔系全体の状態を再現で きると考えられる。

側方滑走開口運動時，いずれの咬合小面間距離にお いてもその面積は下顎の移動とともに，作業側では緩 やかに減少し, 平衡側では急速に減少する傾向が認め られた。またこの変化は $200 \mu \mathrm{m}$ 以下の咬合小面間距 離を示す咬合接触部位については, 作業側では下顎切 歯点の移動距離が咬頭嵌合位から約 $1 \mathrm{~mm}$ までの範囲 で, 平衡側では約 $0.5 \mathrm{~mm}$ までの範囲で大きく変化し ており, それ以上の移動距離をもつ頧位では, 咬合接 触を示す咬合小面すなわち側方滑走運動をガイドする 部位はほとんど変化していない場合が多かった。した がって滑走運動時の咬合接触状態を検討する場合, 下 顎切歯点の移動距離が咬頭嵌合位から約 $1 \mathrm{~mm}$ までの 範囲が特に重要であると考えられる，側方咬合位の咬 合接触様式を決定するにあたり，その額位を明確にし ておく必要があるが, 現在のところ統一された術式は なく, 犬歯, 小臼菌, あるいは第 1 大臼歯の咬頭対咬 頭位 ${ }^{14,15)}$, または下䅡切歯点の移動距離が $3 \mathrm{~mm}$ の頻

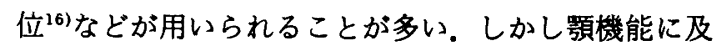
ほす影響が大きいのはこれらの顥位よりもさらに咬頭 嵌合位に近い顥位であると考えられ, 今後, 統一した
術式の確立にはこの点を考虑する必要がある。

前方滑走開口運動時の咬合状態についても，咬合接 触部位の面積は前歯部では緩やかに減少し，臼歯部で は急速に減少した。特に下顎切歯点の移動距離が咬頭 嵌合位から約 $1 \mathrm{~mm}$ の頻位では臼歯部にはほとんど咬 合接触は認められなかった。したがって前方滑走開口 運動においても咬合状態の変化が最も大きいのは, 下 顎切歯点の移動距離が咬頭嵌合位から約 $1 \mathrm{~mm}$ までの 範囲である。

咬頭嵌合位から偏心位へ向かう側方滑走開口運動 と, 偏心位から咬頭嵌合位へ向かう側方滑走閉口運動 では, 切歯点における運動経路だけをみればほとんど 同じような運動経路であっても，機能的には異なった 意味をもつと考えられる.そこで側方滑走運動の開口 路と閉口路について臼歯部での運動経路を詳細に検討 した。 その結果, 作業側では両運動経路に前後的な相 違が認められる場合でも上下的にはほほ一致した経路 を示したが，平衡側では相違がみられる場合が多く， 閉口路が開口路よりも上方の経路をとる場合が多かつ た.すなわち両運動経路上においてほほ同じ移動量を もつ 2 顎位を比較すると, その相違は下顠の回転要素 によるところが大きいと考えられる．また咬合状態で いえば, 開口路よりも閉口路の方が平衡側の上下靧歯 列が近接する傾向にあり, 開口路では認められなかっ た平衡側接触が閉口路では認められることもあり得 る.したがって偏心位において下顎を保持, 固定して 咬合位の記録を行うような場合には，下頻は閉口する 方向にあり, 平衡側接触が出現しやすい傾向にあるこ とを考慮すべきである．またこのような場合に認めら れた平衡側接触は顎機能にとって有害であるとは考え られないが, 平衡側臼歯部における両運動経路が作業 側臼歯部における両運動経路よりも一致するような場 合は, 平衡側臼歯部の咬合接触が側方滑走運動のガイ ドとなっており，有害であると判断できるのではない かと考えられる.

2）咀瀷運動中の咬合状態について

咀礵力が加わった状態では, 生体に歪み, 変形が生 じる ${ }^{13)}$ ので額関節部など歯列から遠い部位ではデータ の精度が悪くなるが, 㮘運動は歯列の部分で測定して いるので, 咀畄運動においても咬合状態に関してはか なり正確に再現できると考えられる。

咀緭運動路については, 一般に切歯点部における運 動経路全体を対象として解析された報告が多いが，咬 合面形態と密接に関係すると考えられる咬頭嵌合位付 
近の詳細な解析報告は数少ない. 藍 ${ }^{1}$ は切歯点部にお ける咬頭嵌合位付近の咀嘪運動路は側方滑走運動路に 近似することを指摘した.しかし臼歯部における両運 動経路の近似性についてはいまだ明らかではなく，顆 頭部にいたつてはいくつかの報告があるが17,18)，その 動態が十分に解明できたとはいい難い.また咀嚼運動 中の咬合状態についてはテレメータリングにより咬合 接触の有無を調べた報告はあるが19 22)，歯列全体を 対象として咬合状態を観察した報告はない.

そこで本研究では咬頭嵌合位付近における咀緭運動 中の咬合状態を側方滑走開口ならびに閉口運動時の咬 合状態と比較することにより, 両者の近似性あるいは 相違点について検討した。

本研究の結果では，咀啷運動中に非咀嚼側にも咬合 接触が認められ, 非咀嚼側の咬合接触が咀嚼側に先行 する場合，あるいは咀嚼側よりも広い面積で咬合接触 する場合が認められた。これを運動経路でみると咀嚼 の第 4 相において，切歯点部ではほほ側方滑走開口運 動と一致している場合でも，非咀嚼側臼歯部では側方 滑走開口運動路よりも上方の経路を描いていた。これ は側方滑走開口運動路と側方滑走閉口運動路で, 閉口 路の方が上方の経路をとることとほほ同じような傾向 にあるといえる．また全部床義歯では咀㘉運動中に非 咀䍛側に咬合接触が認められることが指摘されてお $\eta^{23 \sim 25)}$, これは咀嚼時の義歯の変位，浮き上がりだ けではなく，咀嚼中心を支点とした回転によるもので あるとの考察がなされている ${ }^{26)}$ が，生体でも同様な現 象が起こっている可能性があるといえる.すなわち咀 㘁側では食品が介在し歯の接触が認められない状態で も, 食品を介在した状態で咬合力は発揮されていると 考えられるが，このとき非咀嚼側に咬合接触が認めら れない状態では下額は力学的に不安定な状態であり， より安定した状態をとろうとして咀嘪側を支点とした 下顎の回転が起こるのではないかと推察される。また このとき非咀緭側に認められる咬合接触の部位は, 側 方滑走閉口運動時に咬合接触が認められる部位，ある いは上下顎咬合小面間のクリアランスが少ない部位と 一致していた。したがって側方滑走閉口運動時に認め られる平衡側接触の部位は，咀嚼運動中には下頡を支 持し，安定を図る役割を果たしている可能性もある。 さらに咀嚼の閉口時に非咀嚼側の咬合接触が先行し， 咀喟側に咬合接触が認められず非咀嗐側にのみ咬合接 触が認められるような場合には，非咀嚼側での咬合接 触が下顎を誘導している可能性もある。平衡側接触に
ついては歯周病的立場から咬頭干涉として考える説 ${ }^{27)}$ や，作業側と同時に接触する場合は容認し得るとする 説 ${ }^{28)}$, 筋電図学的に平衡側の接触を好ましくないとす る説 ${ }^{29)}$, あるいは顎関節にとって防護的に働いている とする説 ${ }^{30)}$ な゙があり，いまだ統一した見解は得られ ていない. 本研究では生理的な状態においても咀嚼時 に平衡側接触が認められた。したがってすべての平衡 側接触が生体にとって有害というわけではなく，今 後, 生体にとって望ましい平衡側接触のあり方を定量 的に明らかにする必要があると考えている，また臨床 的にはそのような状態を確認する方法を確立する必要 がある。

咀嚼運動中の咬合状態と側方滑走開口ならびに閉口 運動時の咬合状態を比較した結果では, 咀嚼の閉口時 と側方滑走閉口運動時を比較したときより, 咀獣の開 口時と側方滑走開口運動時を比較したときの方が咬合 状態の一致していることが多かったすすなわち側方滑 走閉口運動時の平衡側となった場合にわずかにクリア ランスをもつ部位であっても, 咀獣の閉口時には非咀 嶰側に咬合接触が認められるという点で側方滑走閉口 運動時とは異なった咬合状態を示していた。これは咀 嚼側に食品が介在していることと強い咬合力が発揮さ れていることの影響であると考えられる.したがって 両者の相違は, 咀噃の閉口時に非咀緭側臼歯部におい て顕著であるといえる。またこのとき非咀嚼側臼歯部 に認められた $1 \mathrm{~mm}$ 以下のクリアランスを示す部位全 体の面積は, 側方滑走閉口運動時よりも咀睘の閉口時 の方が小さいにもかかわらず，咬合接触を示す部位の 面積が大きいという結果から, 咀喟運動中と側方滑走 運動時では厳密には全く同じ顎位をとっておらず，下 顓の動態は異なっていると考えられる。

なお本研究では術者の指定した片側咀嚼運動につい てのみ検討を行ったが，今後はより機能的な状態での 兒慣的咀獣運動の特徵についても検討する必要があ る.

\section{V. 結 論}

1. 歯列の 3 次元形態データと 6 自由度額運動デー タを用いてグラフィックターミナル上で澦運動を再現 し, 機能運動中の咬合接触およびクリアランスについ て 3 次元的に解析することが可能となった.

2. 咀噌運動中には咀㘁側よりも非咀㘁側に強い咬 合接触を認めることがあり，その部位は側方滑走閉口 
運動時の平衡側となった場合に咬合接触が認められる 部位，あるいは上下䪽のクリアランスが小さい部位で あることが確認された。

3. 咬頭嵌合位付近における咀罚運動中の咬合状態 と側方滑走開口ならびに閉口運動時の咬合状態を比較 検討した結果，側方滑走開口運動時と近似した咬合状 態は，咀嚼の開口時に多く認められた。

以上の結果より，側方滑走閉口運動時の平衡側と なった場合にわずかにクリアランスをもつ部位であっ ても，咀嚼運動中に非咀嚼側となった場合には咬合接 触が認められることがある。この状態では，この部位 が下顎を支持し, 誘導している可能性があり, 平衡側 接触の意義についてあらためて考え直す必要のあるこ とが示唆された。

なお本研究の要旨の一部は, 第 84 回日本補綴菌科学会学術大 会（1990 年 10 月 26 日，大阪）において発表した。

\section{文献}

1）藍稔：切曾点部における咀㘁運動の解析, 補緅誌, $6: 164 \sim 200,1962$.

2）中尾勝彦：正常天然歯列における咬合小面と歯牙接触に関 する研究 (咬頭嵌合位), 補緅誌, $14: 1 \sim 21,1970$.

3）中尾勝彦：正常天然宷列における咬合小面と雪牙接触に関 する研究（後方歯牙接触位，前方滑走運動，側方滑走運 動), 補緅誌, $16: 45 \sim 75,1970$.

4）篠塚裕康：歯牙滑走運動における接触状態の観察, 歯科学 報, $72: 605 \sim 646,1972$.

5）内田智幸：歯牙滑走運動時における上下頻臼歯部の接触に 関する研究，歯科学報, $73: 233 \sim 263,1973$.

6）田中義博：成人正常者における咬頭嵌合位および側方運動 時の咬合状態に関する研究 第 2 編 側方運動時作業側の 咬合状態, 補緅誌, $35 ： 863 \sim 877,1991$.

7）大久保由紀子：咬合接触の 3 次元解析システムの開発, 補 緅誌, $36: 53 \sim 63,1992$.

8）藤村哲也, 坂東永一：ディジタル方式類運動測定器の開 発, 補緅誌, $35: 830 \sim 842,1991$.

9）中沢 勇：下䫑運動の補棳学的研究, 有歯額の運動, 口病 誌, $13: 81 \sim 98,1940$.

10）水野 享：咀哷時の歯牙滑走運動に関する研究 第二報 咀程様空口運動時の歯牙滑走運動と曰歯部咬合面形態の比 較, 補緅誌, $33: 303 \sim 312,1989$.

11）加藤 均：歯周組織の機能状態に関する研究 第 2 報 歯の機能時の変位と安静時の脈動, 補緅誌, $26: 133 \sim 147$, 1982.
12）三浦宏之：機能下にある歯牙の水平面内における変位に関 する研究, 補緅誌, $29: 348 \sim 367,1985$.

13）竹内久裕, 藤村哲也，坂東永一：咬合力による頻口腔系の 変形が顎運動解析に及ほすす影響，補綴誌，34：1150〜1161， 1990 .

14) Weinberg L.A. : A cinematic study of centric and eccentric occlusions, J Prosthet Dent, 14:290 293, 1964.

15）藍稔，中野雅徳：額口腔系の形態，機能に関する臨床 的調查 第 2 報 咬合について，補緅誌, 19:385〜390, 1975.

16) Ingervall $B .:$ Tooth contacts on the functional and non -functional side in children and young adults, Arch Oral Biol, $17:$ 191 200, 1972.

17) Gibbs C.H. and Lundeen H.C. : Jaw movements and forces during chewing and swallowing and their clinical significance, Advances in occlusion, 2 32, John Wright • PSG Inc., Boston Bristol London, 1982.

18）鈴木 温, 美馬さとみ，西川啓介ほか：咀鲖運動の 6 自由 度解析, 䫑機能, 6:15〜24, 1988.

19) Anderson, D.J. and Picton, D.C.A. : Tooth contact during chewing, J Dent Res, $36: 21 \sim 26,1957$.

20) Graf H. and Zander H.A. : Tooth contact patterns in mastication, J Prosth Dent, $13: 1055 \sim 1066,1963$.

21) Adams S.H. II and Zander H.A. : Functional tooth contacts lateral and in centric occlusion, J Am Dent Assoc, 69: 465 473, 1964.

22) Schaerer P., Stallard R.E. and Zander H.A. : Occlusal interferences and mastication, An electromyographic study, J Prosth Dent, 17: 438 449, 1967.

23) Yurkstas, A.A. and Emerson, W.H. : A Study of tooth contact during mastication with artificial dentures, J Prosthet Dent, $4: 168 \sim 174,1954$.

24) Kaires, A.K. : A Study of occlusal surface contacts in artificial dentures, J Prosthet Dent, $7: 553 \sim 564,1957$.

25）小林埧一：全部床義歯の咀嚼時における咬合接触の動態 一特に，非咀礵側について一，補緅誌，27：150〜167， 1983.

26）小林蜸一，守澤正幸，渡遑竜登美ほか：テレメータリング による全部床義歯の咬合接触，補綴誌，33：94〜105, 1989

27) Schuyler, C.H. : Factors contributing to traumatic occlusion, J Prothet Dent, 11 : 708 715, 1961.

28）長谷川成男：咬合学序説, 1 265, 医歯薬出版, 東京, 1988.

29）西川啓介：頸運動と咀嘴筋活動に及ほす咬合接触の影㛭, 補緅誌, $33: 822 \sim 835,1989$.

30）皆木省吾, 石井彰夫, 曾根田兼司ほか：顎関節内障の発症 調節メカニスムに関する研究一平衡側防護接触が平衡側額 関節の動態に及ほす影些一, 補綴誌, $34 \cdot 84$ 回特別号 : 56 , 1990. 


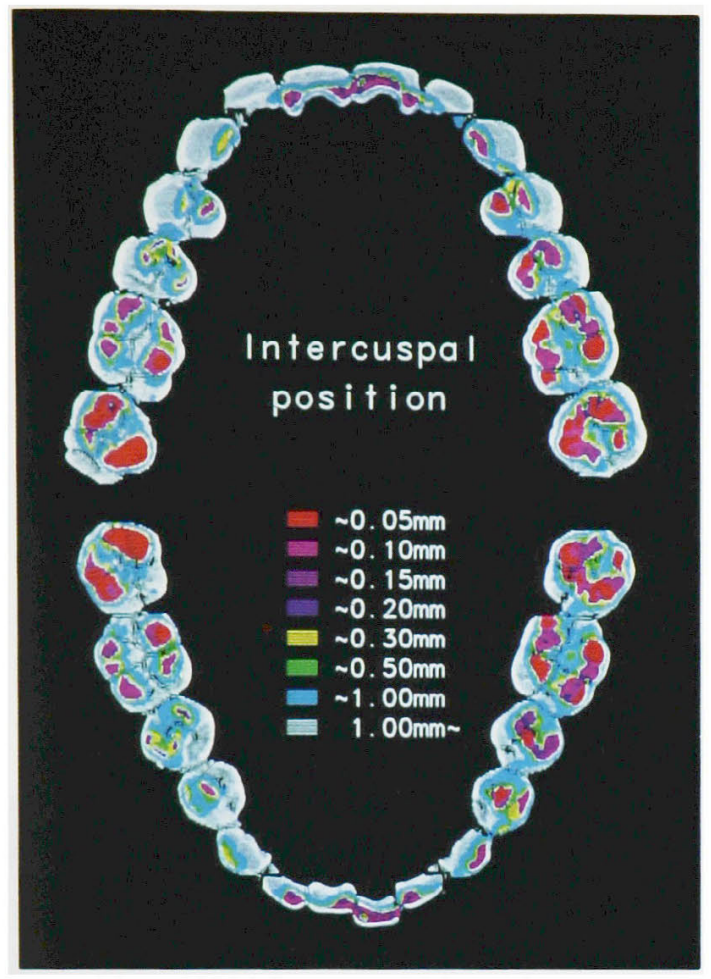

図 1 咬頭嵌合位における咬合状態（被験者 1）

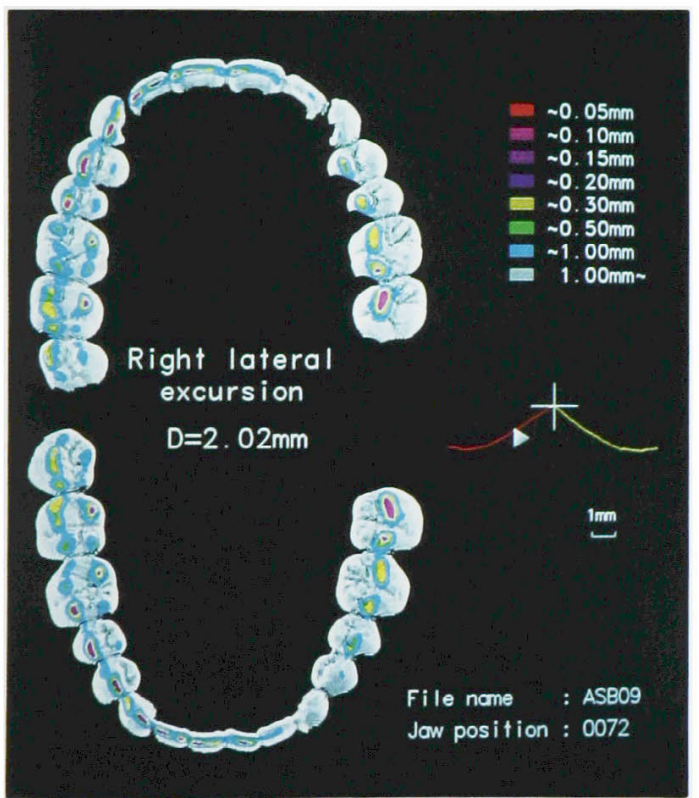

図 3-a 右側方滑走開口運動時の咬合状態（被験者 2) (下額切㐘点の移動距離：約 $2 \mathrm{~mm}$ )

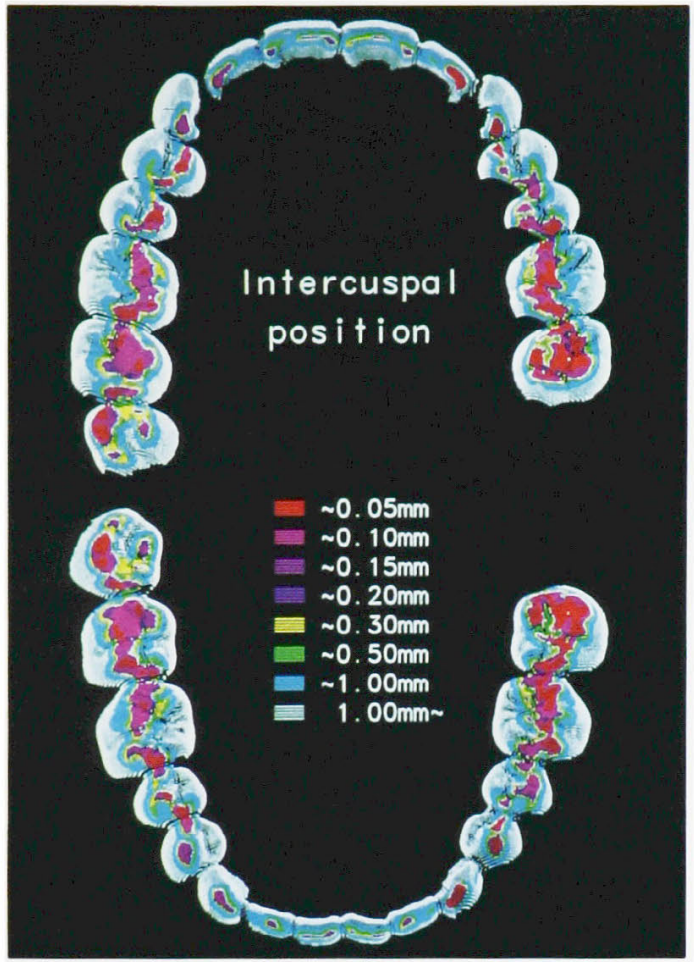

图 2 咬頭嵌合位におりる咬合状態（被験者 2)

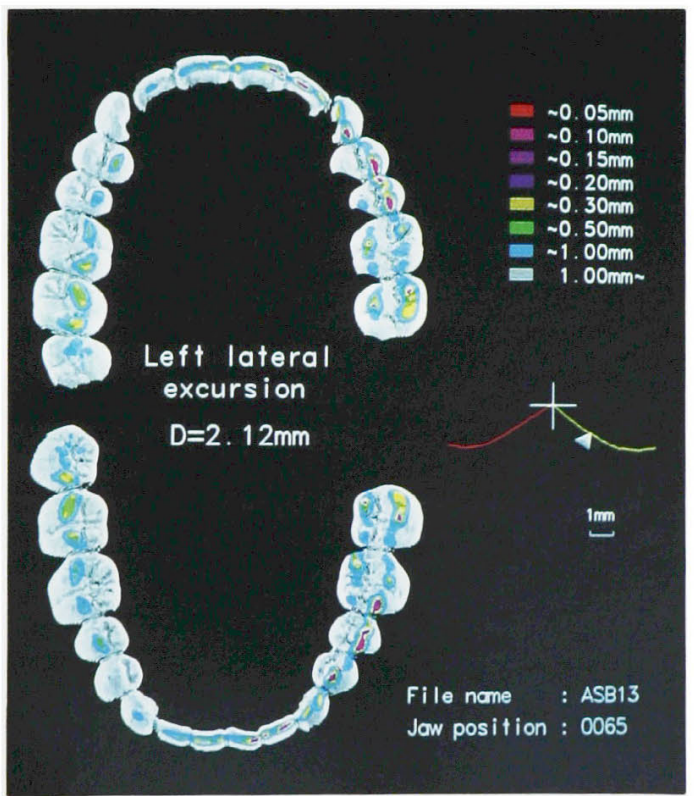

図 3-b 左側方滑走開口運動時の咬合状態（被験者 2） (下額切歯点の移動距離：約 $2 \mathrm{~mm}$ ) 


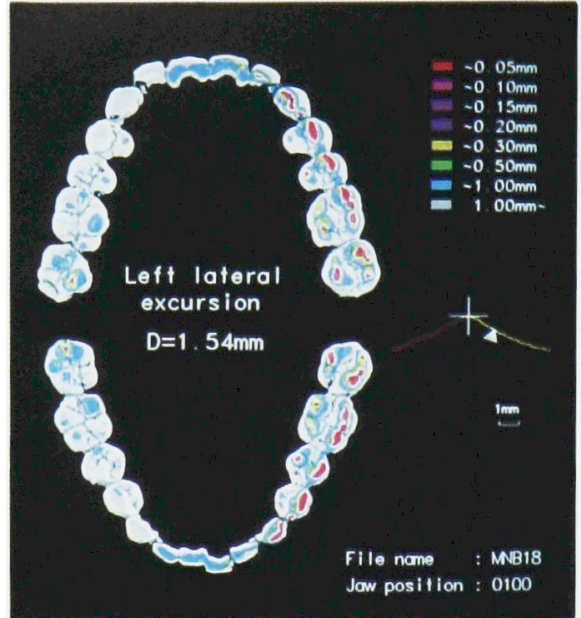

图 6-a 左側方滑走開口運動時の咬合状態（被験者 1） (下顎切歯点の移動距離：約 $1.5 \mathrm{~mm}$ )

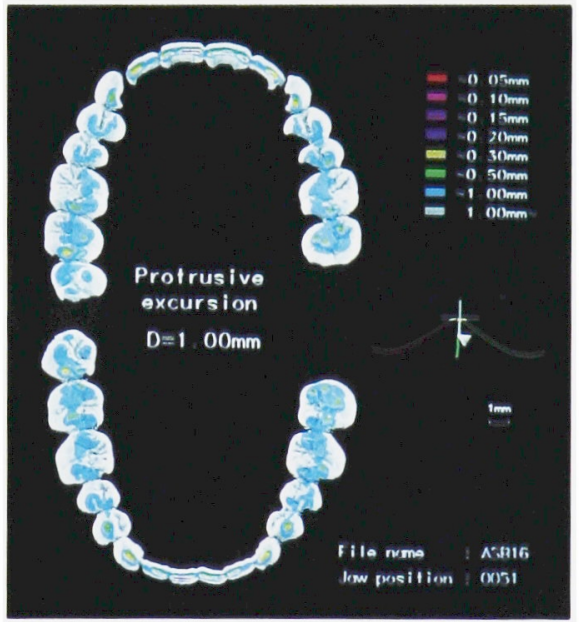

図 7 前方滑走開口運動時の咬合状態（被験者 2) (下頻切歯点の移動距離 : 約 $1 \mathrm{~mm}$ )

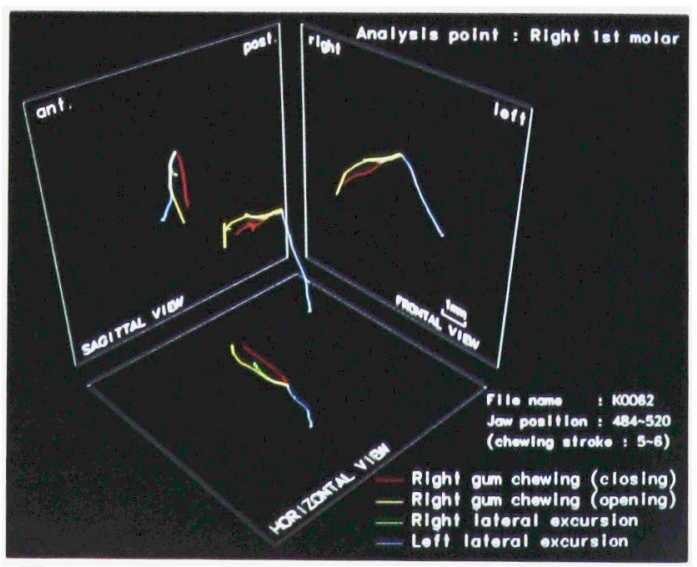

図 9-b 咬頭嵌合位付近における右側ガム咀嚼運動路および 左右側方滑走開口運動路（被験者 4 ：右側第 1 大臼 歯部)

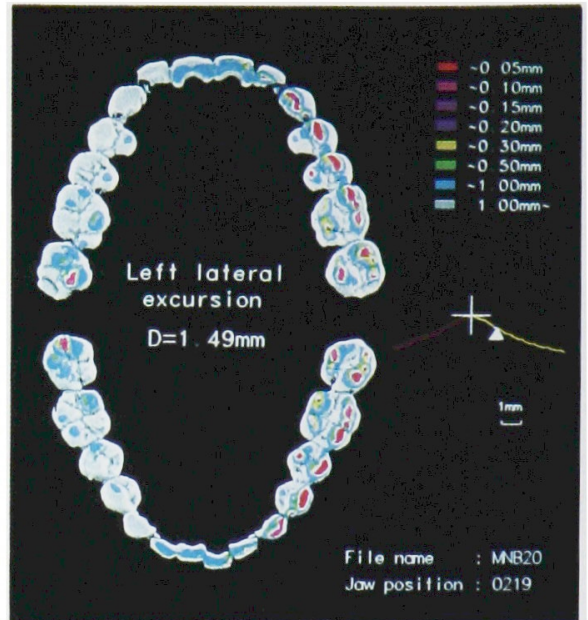

图 6-b 左側方滑走閉口運動時の咬合状態（被験者 1) (下說切歯点の移動距離：約 $1.5 \mathrm{~mm}$ )

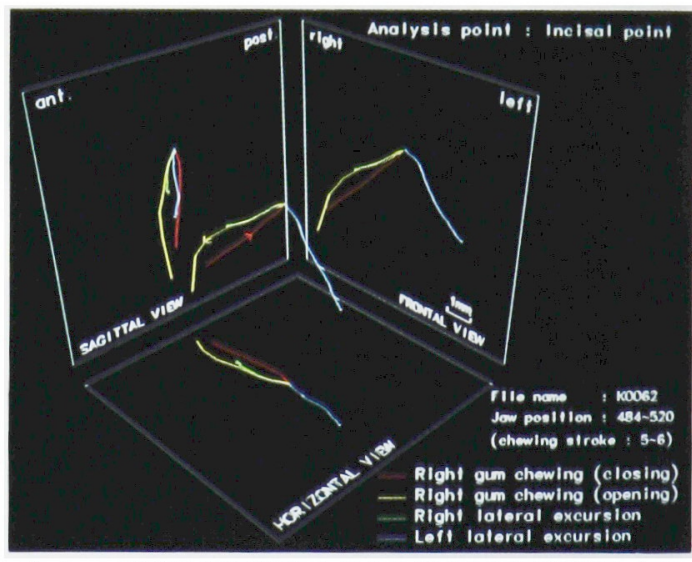

图 9-a 咬頭嵌合位付近における右側ガム咀謤運動路および 左右側方滑走開口運動路（被験者 4 : 切歯点部）

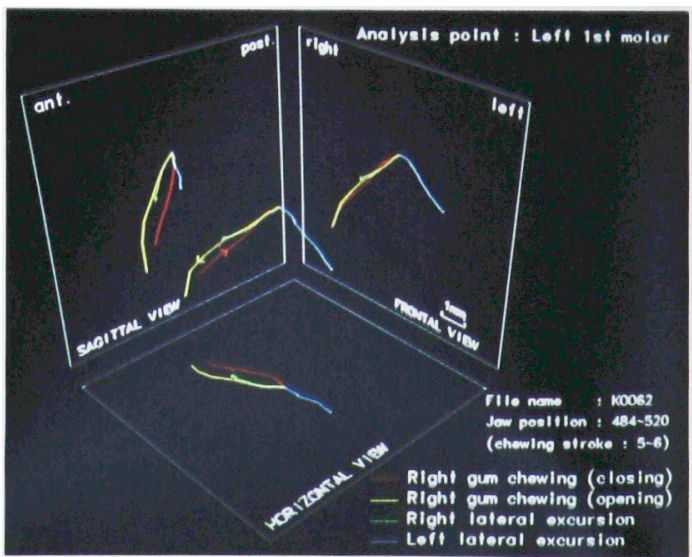

図 9-c 咬頭嵌合位付近における右側ガム咀嘴運動路および 左右側方滑走開口運動路（被験者 4 ：左側第 1 大臼 歯部) 


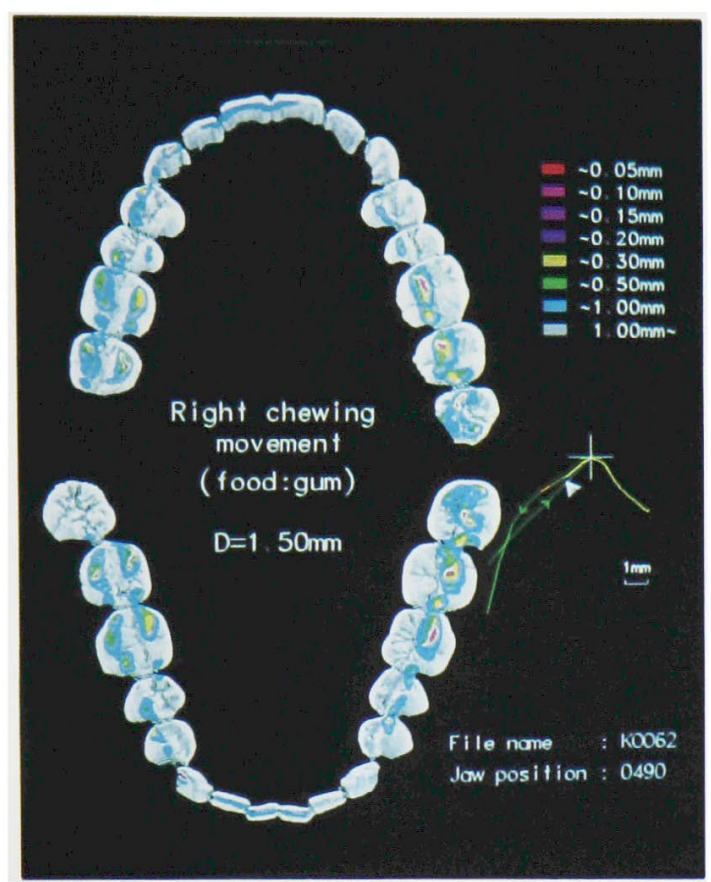

図 10-a

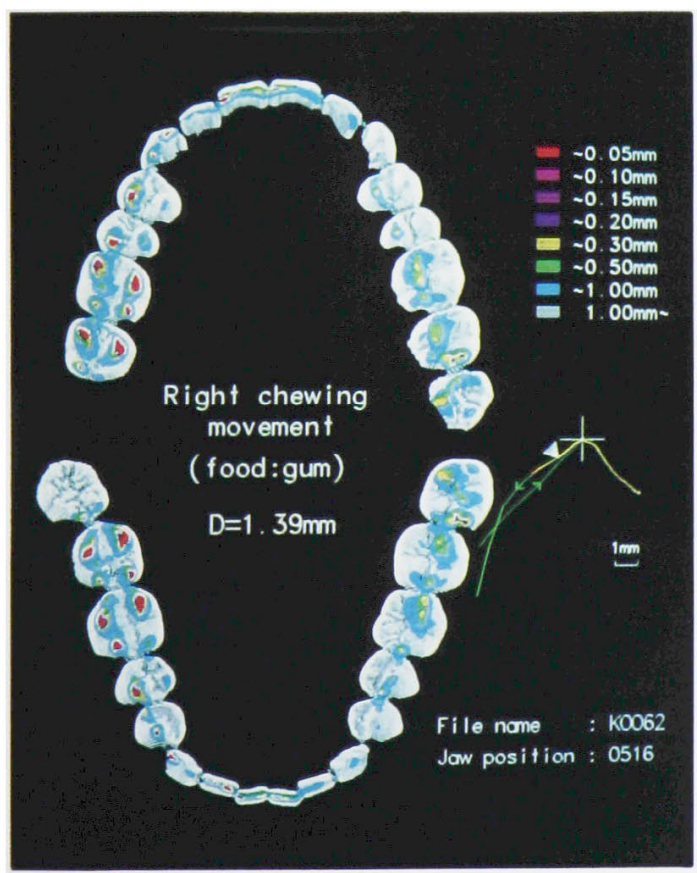

図 10-c

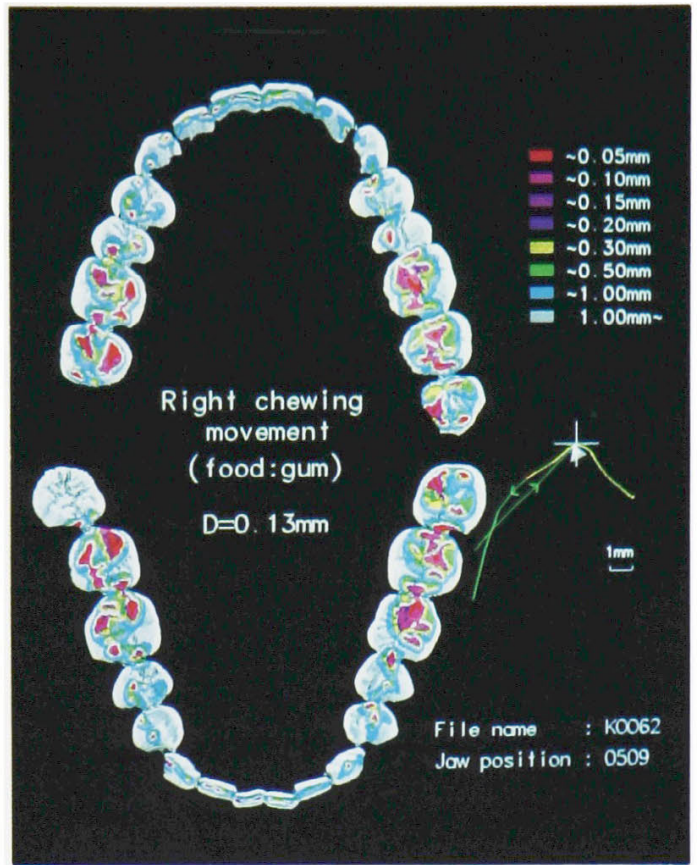

図 10-b

図 10-a 右側ガム咀嚼運動中（閉口時）の咬合状態（被験 者 4)

(下額切歯点の移動距離：約 $1.5 \mathrm{~mm}$ )

図 10-b 右側ガ么咀喼運動中の咬合状態（被験者 4) (下顎切歯点の移動距離 : 約 $0 \mathrm{~mm}$ )

图 10-c 右側ガム咀獣運動中（開口時）の咬合状態（被験 者 4 )

(下顎切崡点の移動距離：約 $1.4 \mathrm{~mm}$ ) 


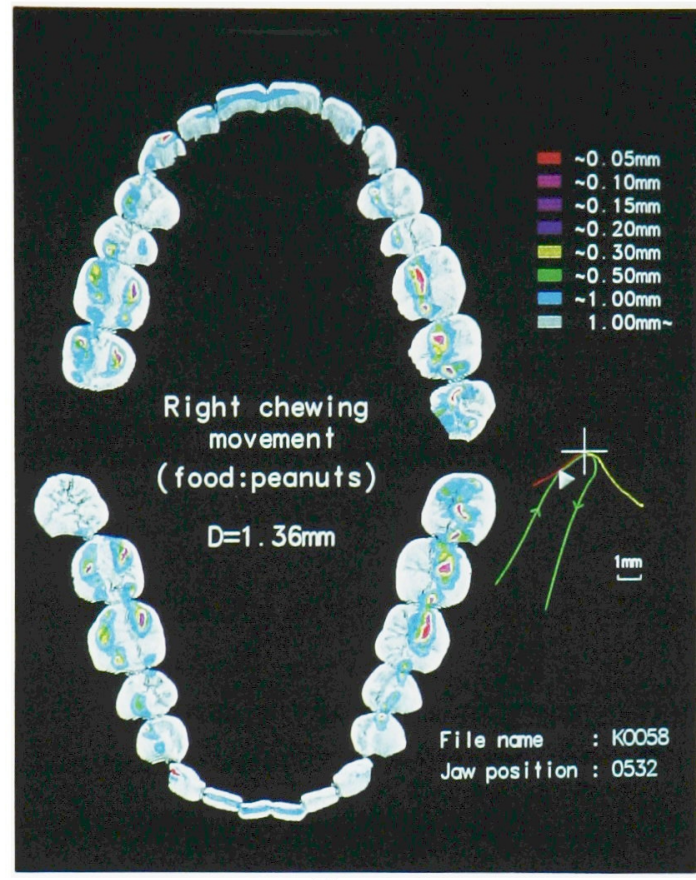

図 12-a

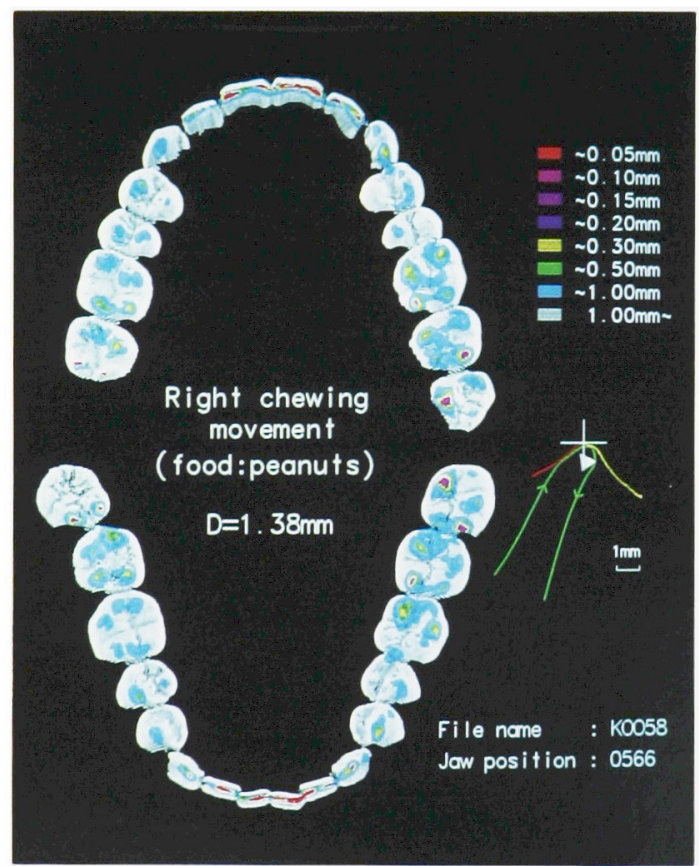

図 12-c

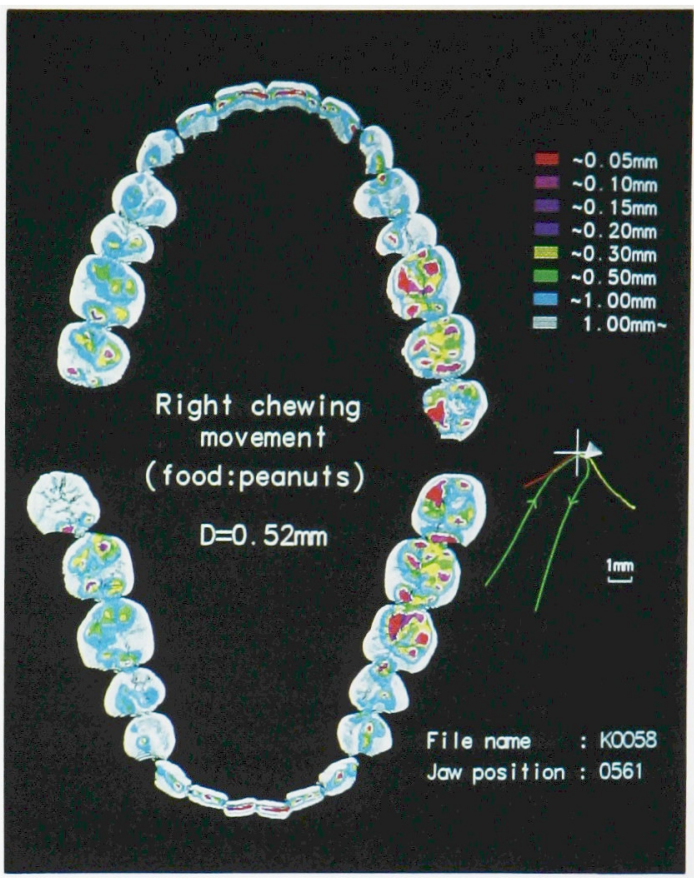

図 12-b

図 12-a 右側ピーナッツ咀嚼運動中（閉口時）の咬合状態 (被験者 4 )

(下顎切歯点の移動距離：約 $1.4 \mathrm{~mm}$ )

図 12-b 右側ピーナッツ咀罟運動中の咬合状態（被験者 4) （下顎切歯点の移動距離：約 $0.5 \mathrm{~mm}$ )

図 12-c 右側ピーナッッ咀唃運動中（開口時）の咬合状態 (被験者 4)

(下顎切歯点の移動距離：約 $1.4 \mathrm{~mm}$ ) 